WHAT SHOULD THE BOARD OF MANAGEMENT OF A PENSION FUND CONSIDER WHEN DEALING WITH DEATH CLAIMS INVOLVING SURVIVING COHABITANTS? 


\section{WHAT SHOULD THE BOARD OF MANAGEMENT OF A PENSION FUND CONSIDER WHEN DEALING WITH DEATH CLAIMS INVOLVING SURVIVING COHABITANTS?}

MO Mhango*

\section{Introduction}

In an article published in 2008, it was argued that the two-pronged factual dependency test for surviving cohabitants, which was formulated in 1998 and has since then been applied by the Pension Funds Adjudicator (hereafter the Adjudicator), should be welcomed because it advances the legislative intent as reflected in Section 37C read with the definition of a "dependant" in the Pension Funds Act. $^{1}$ The inquiry under this test is, firstly, whether the parties (that is the deceased member and surviving cohabitant) lived in a relationship of mutual dependence; and secondly, whether the parties ran a shared and common household. According to the Adjudicator, the first prong of the test is qualified by the requirement that mutual dependency must involve, amongst other things, an emotional and intimate or sexual bond. In the same article, it was demonstrated that following the Constitutional Court decision in Volks $v$ Robinson ${ }^{2}$ a grey area, arising from the conflicting interpretations of the factual dependency test as applied by the Adjudicator, had emerged and the article called on the then Adjudicator Mamodupi Mohlala to clarify the uncertainties created in the law by earlier conflicting interpretations of the Act. Since then, the issue of whether a cohabitant qualifies as a factual dependant was determined by the Adjudicator in Hlathi $v$ University of Fort Hare Retirement Fund. ${ }^{3}$ In this case, the Adjudicator ruled that a cohabitant qualifies as a factual dependant as long as it can be established he/she and the deceased pension member were in a permanent relationship of mutual dependency or interdependency, and that they shared a common household.

\footnotetext{
* Mtendeweka Owen Mhango. BA (Morehead State University) JD (Michigan State University) LLM (Wayne State University). Senior Lecturer, School of Law, University of Witwatersrand.

124 of 1956. See Mhango 2008 SA Merc LJ 126.

2 Volks $v$ Robinson 20055 BCLR 446 (CC) - hereafter Volks.

320091 BPLR 37 (PFA) - hereafter Hlathi.
} 
In this note, it is argued that Hlathi should be welcomed by the pension funds industry because it clarifies the uncertain legal position that emerged in the wake of the judgment in Volks. Briefly, prior to Volks and according to the decision of the former Adjudicator John Murphy in Van der Merwe $v$ Southern Life Association ${ }^{4}$, the board of management of a pension fund (hereafter the Board) has the discretion to accord to same-sex couples and cohabitants the same rights as are accorded to heterosexual married couples. ${ }^{5}$ This view differed from that of the subsequent Adjudicator Vuyani Ngalwana, who, following the decision in Volks, decided in Van der Merwe $v$ Central Retirement Annuity Fund ${ }^{6}$ that a person who could have married a deceased pension member but chose not to, should not be granted the rights of a spouse of the deceased member. ${ }^{7}$ In light of these conflicting decisions, pension funds were uncertain on the manner in which to dispose of death claims by surviving cohabitants. This uncertainty was clarified in Hlathi by reverting to the preVan der Merwe legal position. In other words, the current legal position is in accordance with the position first articulated by Murphy in Southern Life Association in 1998.

This note also comments on the requirements in and implications of Hlathi for the pension funds industry and pension beneficiaries, and criticises the Adjudicator's determination as failing to expressly incorporate the emotional and intimate or sexual bond requirement in the new factual dependency test. It is argued that while Hlathi appears to have reverted to the legal position that prevailed prior to Van der Merwe, the new test does not expressly incorporate the relevant requirement that a relationship of mutual dependence involve an emotional and intimate or sexual bond. As a result, the note is critical of this omission because it creates a potentially new uncertainty in the law, and calls on the current Adjudicator to clarify this matter. While the facts of the case may not have created the necessity to expressly incorporate the latter requirement, this note submits that what the Adjudicator ought to have done is to expressly incorporate or reject the emotional and intimate or sexual bond requirement as it did with the dominant-servient test.

4 Van der Merwe v Southern Life Association 20003 BPLR 321 (PFA) - hereafter Southern Life Association.

5 See Martin v Beka Provident Fund 20002 BPLR 196 (PFA) 213 (hereafter Martin); Southern Life Association 330.

620055 BPLR 463 (PFA) - hereafter Van der Merwe.

7 Van der Merwe 467. 


\section{A brief overview of the purpose of Section 37C}

Section 37C was enacted and inserted into the Act in 1976. This section regulates the payment of any benefit payable upon the death of a pension fund member, and places a duty on the Board to distribute the death benefit. The term "pension fund" is defined in Section 1 of the Act to mean a "pension fund organisation". The term "pension fund organisation" is in turn defined as:

any association of persons established with the object of providing annuities or lump sum payments for members or former members of such association upon their reaching retirement dates, or for the dependants of such members or former members upon the death of such members or former members. ${ }^{8}$

In addition, the language of Section $37 \mathrm{C}(1)^{9}$ of the Act provides that:

regardless of the provisions of any other law, including the common law and notwithstanding the rules of a registered fund, any benefit payable upon the death of a pension member must be dealt with in terms of the scheme outlined in the Act. ${ }^{10}$

Section 37C therefore overrides the freedom of testation in relation to the benefits payable by a pension fund in the event of death of a pension fund member, and gives the discretionary powers to distribute such benefits to the Board. ${ }^{11}$ The guiding

8 Chap 1 Pension Funds Act.

9 Notwithstanding anything to the contrary contained in any law or in the rules of a registered fund, any benefit (other than a benefit payable as a pension to the spouse or child of the member in terms of the rules of a registered fund, which must be dealt with in terms of such rules) payable by such a fund upon the death of a member, shall, subject to a pledge in accordance with section 19 (5) (b) (i) and subject to the provisions of sections $37 \mathrm{~A}(3)$ and 37D, not form part of the assets in the estate of such a member ...

10 Marx and Hanekom Manual 176. See Sithole v ICS Provident Fund 20004 BPLR 430 (PFA) hereafter Sithole - in which the Adjudicator set aside the Board's decision because the Board relied on customary law instead of S 37C to distribute the benefits, and ruled that S 37C specifically takes precedence over any law, which includes customary law. See also Jacobs $v$ Central Retirement Annuity Fund 20011 BPLR 1488 (PFA), which held that the fact that the second respondent lodged a claim against the estate in terms of the Maintenance of Surviving Spouses Act 27 of 1990 has no bearing on the payment of death benefits arising out of the rules of a pension fund. This payment is exclusively regulated by S 37C, regardless of any other law or rules of a fund. See also Matene $v$ Noordberg Group Life-Assurance Scheme 20012 BPLR 1604 (PFA) and Kaplan $v$ and Another NNO $v$ Professional and Executive Retirement Fund and Others 200110 BPLR 2541 (W).

11 See Wood-Bodley 2007 SALJ 687 for a discussion on the freedom of testation under South African law. 
principle is that such assets do not form part of the deceased's estate, nor do the provisions of the intestate succession legislation apply, but are required to be distributed in accordance with the statutory scheme, which gives preference to need and dependency above the pension fund member's choice. ${ }^{12}$ Effectively, in terms of Section 37C, the needs of dependants override decisions on the manner in which a member's pension savings should be distributed.

The policy underlying this social security measure is to ensure that the monies in respect of which the state allows major tax concessions should, in theory, be applied towards the benefit of the deceased member's surviving spouse, children and other dependants, thereby reducing the state's liability and promoting social protection. ${ }^{13}$ Therefore, the primary purpose of this section is to prevent dependants of pension fund members from being left without financial support, and to this end it gives the Board the power to implement this social security measure and minimise obligations of the state to support surviving dependants. ${ }^{14}$ Commenting on the purpose of Section 37C, Hussain $J$ of the South Gauteng High Court (formerly the Johannesburg High Court) in Mashazi $v$ African Products Retirement Benefit Provident Fund ${ }^{15}$ explained that:

Section 37 of the Act was intended to serve a social function. It was enacted to protect dependency, even over the clear wishes of the deceased. The section specifically restricts freedom of testation in order that no dependants are left without support. [It] specifically excludes the benefits from the assets in the estate of a member, [and] enjoins the trustees of the pension fund to exercise an equitable discretion, taking into account a number of factors.

To achieve this purpose, the legislature embraced a broad definition of "dependant" in the Act. This definition reads as follows:

dependant, in relation to a member, means-

12 Dobie v National Technikon Retirement Pension Fund 19999 BPLR 29 (PFA); Mthiyane $v$ Fedsure Life Assurance Ltd 20017 BPLR 2230 (PFA).

13 Mashazi; Van de Berg $v$ Durban Pension Fund 20033 BPLR 4518 (PFA); Musgrave $v$ Unisa Retirement Fund 20004 BPLR 415 (PFA) - hereafter Musgrave. See Marx and Hanekom (n 10) 177.

14 Musgrave. For a discussion of the purpose and rationale of S 37C, see also, e.g. Manamela 2005 SA Merc LJ 278-279.

1520028 BPLR 3703 (W) 3705-3706 (hereafter Mashazı). 
(a) a person in respect of whom the member is legally liable for maintenance;

(b) a person in respect of whom the member is not legally liable for maintenance, if such person-

(i) was, in the opinion of the Board, upon the death of the member in fact dependent on the member for maintenance;

(ii) is the spouse of the member;

(iii) is a child of the member, including a posthumous child, an adopted child and an illegitimate child;

(c) a person in respect of whom the member would have become legally liable for maintenance, had the member not died ... ${ }^{16}$

What should be clear from the above definition is that the Act creates three categories of dependants. The first is a legal dependant under subsection (a). The second is a factual dependant under subsection (b). The third is a future dependant under subsection (c). While the legislature's worthy intentions in enacting Section $37 \mathrm{C}$, read with the definition of "dependant", are admirable, the Adjudicator has critically observed that Section 37C:

is a hazardous, technical minefield potentially extremely prejudicial to both those who are expected to apply it and to those intended to benefit from its provisions. It creates anomalies and uncertainties rendering it most difficult to apply. There can be no doubt about its noble and worthy policy intentions. The problem lies in the execution and the resultant legitimate anxiety felt by those who may fall victim to a claim of maladministration in trying to make sense of it. Any successful claim for maladministration will be borne ultimately by the other members, the participating employer, or perhaps even the members of the board of management. One admirable aspect of the section is its worthy intention to protect dependants who do not reside in the same vicinity as the deceased member. One thinks here naturally of migrant labourers working in the urban areas with dependants in remote rural areas. By imposing a duty on the board to trace dependants the section advances such persons interests. However, there is legitimate concern about the practical difficulties of tracing such dependants. One solution may be for the section to identify more precisely the steps required to be taken, including an appropriate form of publication, and then allowing for a final distribution to known dependants and nominees at the expiry of a reasonable period culminating in indemnification of the board against further claims. Further discussion and consideration is obviously required. ${ }^{17}$

The difficulties brought about by Section 37C arise out of the three duties this section imposes on the Board. The first of these duties is to identify the dependants of a

16 Chap 1 Pension Funds Act, as amended by the Pension Funds Amendment Act 11 of 2007.

17 Dobie NO v National Technikon Retirement Pension Fund 19999 BPLR 29 (PFA) 41F-J. 
member. The second duty is to effect an equitable distribution of the benefits amongst the beneficiaries, and the third is to determine an appropriate mode of payment. In the discussion that follows, this note will focus on the first duty imposed on the Board, which is to identify potential dependants. ${ }^{18}$

\section{$3 \quad$ Factual background}

In Hlathi, the complainant was the mother of the deceased, and the executrix of the deceased member's estate. The deceased was a member of the Fort Hare Retirement Fund (hereafter the Fund) until he passed away on 27 March $2002 .{ }^{19}$ At the time of his death, he was cohabiting with the third respondent, Ms Hanise. Following his death, a benefit of R400,000.00 (before tax deductions) became available for distribution to his beneficiaries. The Board of the Fund identified the complainant and Ms Hanise as the deceased's dependants. The Board - after conducting an investigation pursuant to Section 37C - resolved to allocate thirtythree per cent of the benefit to the complainant and sixty-six per cent to Ms Hanise. ${ }^{20}$ The complainant lodged a complaint objecting to this proposed distribution. She alleged that Ms Hanise was not the deceased's dependant because she was employed in a high-paying job, and that she (the complainant) was the sole beneficiary, as the deceased was unmarried and did not have any children. ${ }^{21}$ As a result, the complainant lodged a complaint with the Office of the Pension Funds Adjudicator (OPFA) and sought to set aside the Board's distribution and replace it with an order allocating one hundred per cent of the benefits in her favour. ${ }^{22}$

In response, the Board stated that it had conducted an investigation following the death of the deceased, which revealed that the deceased had two dependants. ${ }^{23}$ According to the Board, these dependants were Ms Hanise and the complainant. In addition, the Board's investigation revealed that Ms Hanise was living with the

18 Ramanyelo v Mine Workers Provident Fund 20051 BPLR 67 (PFA) - hereafter Ramanyelo; Malatjie $v$ Idwala Provident Fund 20051 BPLR 45 (PFA) - hereafter Malatjie. See Marx and Hanekom (n 10) 175.

19 Hlathi Para 2.

20 Hlathi Para 4.

21 Hlathi Para 5.

22 Hlathi Para 6.

23 Hlathi Para 7. 
deceased as husband and wife, and had produced proof of shared expenses, which demonstrated that she was financially dependent on the deceased. ${ }^{24}$ The Board's investigation also revealed that in arriving at its decision to distribute the death benefits, it took into account the fact that the complainant, as the executrix of the deceased estate, had access to an amount of $R 327,850.18$ from a group life assurance policy and another accidental death benefit policy that was paid into the estate. $^{25}$

Ms Hanise, who was joined as a party to the complaint in terms of Section $30 \mathrm{G}$ (d) of the Act, filed a response to the complaint. ${ }^{26}$ In her response, she explained that she had had a formal relationship with the deceased that lasted for a period of seventeen years, and that they lived together as husband and wife for a period of nine years until his death, and furnished proof that indicated that the deceased regarded her as his lifelong partner (namely by giving her signing powers on his bank account). ${ }^{27} \mathrm{Ms}$ Hanise stated that they had a mutually supportive, loving and happy relationship. She provided detailed proof of shared expenses, including a $50 \%$ contribution towards bond repayments, household insurance, motor vehicle insurance and maintenance costs, telephone costs, family holidays, and general entertainment costs. ${ }^{28}$ Furthermore, she contributed financially towards the deceased's tuition and maintenance whilst he was studying in Cape Town because she was his only source of financial support at the time. Ms Hanise stated that they had plans to be married at the end of 2002 when the deceased completed his studies. She explained that her financial position had changed since the death of the deceased. ${ }^{29}$

\section{Rationale and decision}

According to the Adjudicator, the main issue for determination was whether the death benefit was properly and lawfully allocated to Ms Hanise by the Board, in consequence of a rational decision. In resolving this issue, the Adjudicator correctly observed that the payment of death benefits is regulated by Section $37 \mathrm{C}$ read with

24 Hlathi Para 8-9.

25 Hlathi Para 10.

26 Hlathi Para 12.

27 Hlathi Para 13.

28 Hlathi Para 13.

29 Hlathi Para 14. 
the definition of "dependant" in Section 1 of the Act, and that when dealing with these matters, the Board has to fulfil three responsibilities. Firstly, it has to determine the dependants of the deceased; secondly, it has to decide on an equitable distribution of the available benefits; and thirdly, it has to decide on the most appropriate mode of payment. ${ }^{30}$

In this matter, the Adjudicator noted that the Board, in relation to its first responsibility, identified two dependants, namely the complainant and Ms Hanise. ${ }^{31}$ In relation to the complainant, the Adjudicator further observed that a dependant in terms of Section 1 of the Act is defined to include, amongst other things, persons in respect of whom the member (in this case the deceased) would have become legally liable to maintain, had the member not died. ${ }^{32}$ Accordingly, the Adjudicator ruled that the complainant fell within this category of dependants, presumably because the deceased would have become legally liable to maintain her, had he not died. ${ }^{33}$ This was substantiated by a sworn affidavit that demonstrated that the complainant was being maintained by the deceased and that this was likely to turn into a legal responsibility had he not died. As a result, the Adjudicator ruled that the Board correctly relied on the complainant's sworn affidavit to confirm her status as a dependant. $^{34}$

In relation to Ms Hanise, the Adjudicator observed that Ms Hanise was cohabiting with the deceased in a lifelong relationship at the time of his death, and that the Board had classified her as a common law spouse of the deceased..$^{35}$ Therefore, one of the questions that arose for the Adjudicator was whether there is a distinction in law between a cohabitant and a common law spouse that would affect whether Ms Hanise qualified as a dependant under Section 1 of the Act. Regarding this question, the Adjudicator reasoned that there was no difference between a

30 Hlathi Para 18. See also Ramanyelo and Malatjie.

31 Hlathi Para 19.

32 For an example of other individuals who have qualified under this provision, see Van Zyl v Delta Motor Corporation Salaried Provident Fund PFA/EC/698/04/Z/CN, which held that a deceased member's fiancée qualified as a future dependant and was consequently awarded death benefits; Wellens v Unsgaard Pension Fund 200212 BPLR 4214 (PFA), which held that parents of the deceased qualified as future dependants; Wasserman v Central Retirement Annuity 20016 BPLR 2160 (PFA).

33 Hlathi Para 20.

34 Hlathi Para 20.

35 Hlathi Para 21. 
cohabitant and a common law spouse because these terms are used interchangeably by legal academics. ${ }^{36}$ Therefore, the remaining relevant question was whether Ms Hanise qualified as a dependant pursuant to the Act. In determining this question, the Adjudicator observed that the Act in Section $1 \mathrm{~b}$ (ii) recognises and defines a spouse of a member as a dependant. ${ }^{37}$ The relevant sections read as follows:

dependant, in relation to a member, means -

(a) $\ldots$

(b) a person in respect of whom the member is not legally liable for maintenance, if such person -

(i) $\quad \ldots$;

(ii) is the spouse of the member;

spouse means a person who is the permanent life partner or spouse or civil union partner of a member in accordance with the Marriage Act, 1961 (Act No. 68 of 1961), the Recognition of Customary Marriages Act, 1998 (Act No. 68 of 1997), or the Civil Union Act, 2006 (Act No. 17 of 2006), or the tenets of a religion. ${ }^{38}$

In light of this recognition, the question to be determined by the Adjudicator was whether Ms Hanise qualified as a spouse. The Adjudicator initially reasoned that since Ms Hanise had a formal relationship with the deceased, which lasted for a period of seventeen years, of which nine years were spent as a husband and wife, she was satisfied that the deceased and Ms Hanise were permanent life partners, and therefore the latter probably qualified as a spouse by virtue of being regarded as a spouse in terms of the amended definition of "spouse" in the Act. ${ }^{39}$ Nevertheless, the Adjudicator argued that Ms Hanise was disqualified as a spouse for two reasons. The first was that the new definition of "spouse" in the Act did not have retrospective application, given that it came into operation on 13 September 2007, while the deceased had passed away on 27 March 2002. The Adjudicator also noted that the 2007 amendments to the Act had expressly indicated the provisions that would apply retrospectively, and the definition of a spouse was not one of them. ${ }^{40}$ The second

36 Hlathi Para 22.

37 Hlathi Para 23.

38 S 1 Pension Funds Act, as amended by the Pension Funds Amendment Act.

$39 \mathrm{~S} 1$ Pension Funds Act, as amended by the Pension Funds Amendment Act. See Hlathi para 28.

$40 \mathrm{~S} 1$ Pension Funds Act, as amended by the Pension Funds Amendment Act. See Cockcroft $v$ Mine Employees Pension Fund 20073 BPLR 296 (PFA), which held that the provisions in the 
reason was that Ms Hanise and the deceased had not solemnised their relationship in accordance with the Civil Union Act. ${ }^{41}$

Since Ms Hanise did not qualify as a legal dependant under Section 1 (b)(ii), the next question the Adjudicator had to consider was whether she qualified as a factual dependant under Section 1 (b)(i). ${ }^{42}$ The Adjudicator reasoned that the evidence before her was sufficient to bring Ms Hanise within the meaning of a factual dependant, and concluded that the Fund was correct in considering her in the distribution of the benefits. In reaching this conclusion, the Adjudicator rejected a previous ruling by the Adjudicator in Van der Merwe, which held that factual dependency requires a dominant-servient relationship, in which one party is the substantive provider. $^{43}$ In determining whether Ms Hanise qualified as a factual dependant pursuant to Section 1(b)(i), the Adjudicator first observed that under the test in Van der Merwe, Ms Hanise would only qualify as a factual dependant were she able to establish that the deceased was the substantive provider in their relationship. ${ }^{44}$ Essentially, the test required the Board, in exercising its powers under Section 37C, to regard Ms Hanise as a factual dependant in circumstances in which she was able to establish that the deceased member was the dominant financial provider in their relationship.

In determining the validity of the requirement of a dominant-servient relationship in the Act and its applicability to the facts of this case, the Adjudicator rejected this dominant-servient test, and noted that Section 1(b)(i) of the Act does not contemplate a dominant-servient relationship in which a pension member is the dominant person who maintains the dependant immediately prior to his or her death, as a basis for qualifying as a factual dependant. Furthermore, the Adjudicator reasoned that a purposive and contextual interpretation of Section 1 (b)(i) reveals that the intention of the legislature was to give effect to the purpose of Section 37C, which is to protect proven dependency even for persons who are involved in a relationship that the law does not necessarily accept as constituting a legal

Pension Funds Amendment Act relating to divorce benefits were intended to apply retrospectively.

4117 of 2006.

42 Hlathi Para 31.

43 Hlathi Para 33.

44 Hlathi Para 32. 
dependency. ${ }^{45}$ According to the Adjudicator's reasoning, since the legislature does not refer to the terms "totally" or "wholly" dependent in the provisions of Section 1 (b)(i), there is no exhaustive list of degree or levels of dependency. Contrary to the suggestion in Van der Merwe, total dependency is consequently not the sole measure by which to determine dependency for purposes of Section 1 (b)(i). ${ }^{46}$

Accordingly, it would be contrary to the legislative intent to exclude a party for purposes of Section 1 (b)(i) of the Act, on the basis that he/she had an interdependent relationship with a deceased member or that the parties had an equal relationship as opposed to a dominant-servient one. Based on the forgoing rationale, the Adjudicator ruled that in cases arising under Section 1 (b)(i) involving a surviving cohabitant it was sufficient to prove that the party seeking benefits was in a permanent relationship of mutual dependence or interdependence and ran a shared and common household with the deceased, and as a consequence of the other party's death he/she was financially worse off. ${ }^{47}$

In applying the above principle to this matter, the Adjudicator found that Ms Hanise and the deceased contributed equally towards bond payments of both their homes and other household expenses. The Adjudicator also found it significant that the parties mutually supported each other in a relationship that lasted for a period of seventeen years, and that Ms Hanise's financial position had dramatically changed since the deceased's death. Based on these findings, the Adjudicator ruled that Ms Hanise fell within the scope of the definition of a factual dependant as set out in Section 1 (b)(i) of the Act, and was correctly regarded as a dependant by the Board. $^{48}$

The Adjudicator also considered the second responsibility of the Board, which, as indicated above, requires it to decide on an equitable distribution of the benefits amongst all identified dependants. ${ }^{49}$ In determining whether the Board acted

\footnotetext{
45 Hathi Para 34.

46 Hlathi Para 34.

47 Hlathi Para 34.

48 Hlathi Para 35.

49 Hlathi Para 36.
} 
equitably in the distribution of the benefits, the Adjudicator observed that in making its decision, the Board needed to consider all relevant information and ignore irrelevant factors. Furthermore, the Board should not rigidly adhere to a policy or fetter their discretion in any other way. ${ }^{50}$ The Adjudicator also noted that her duty was not to decide what the fairest or most generous distribution was, but to determine whether the Board had acted rationally and arrived at a proper and lawful decision. ${ }^{51}$ Consequently, the Adjudicator could only set aside the Board's decision should it have exercised its discretionary powers unreasonably and improperly.

In the present matter, the Adjudicator found that the Board allocated sixty-six per cent of the benefits to Ms Hanise because its investigation revealed that she ran a common household with the deceased for nine years, and that they were interdependent as confirmed by evidence of shared expenses. It is important to mention that the Adjudicator did not consider the third responsibility, which requires the Board to make an appropriate mode of payment, because it was not pertinent to the matter. Considerations of the third responsibility typically arise when a minor beneficiary is involved..$^{52}$ The Adjudicator was satisfied that the Board acted reasonably and properly and considered relevant factors in settling upon its decision, and as a result there were no legal grounds to alter the Board's decision in the matter.

\section{The Implications of Hlathi v University of Fort Hare Retirement Fund}

Hlathi is important and should be welcomed by the pension funds industry because it clarifies a grey area and brings finality to the law. Previously and in light of the decision in Volks, a grey area emerged in pension law because of the different decisions by the Adjudicator. According to a decision by Murphy, the Board had the discretion to accord to same-sex couples and cohabitants or life partners the same rights as are accorded to heterosexual married couples. ${ }^{53}$ Murphy's decision was motivated by the desire to prevent pension funds from discriminating on the basis of marital status, as provided by Section 9 of the Constitution of the Republic of South

50 Sithole.

51 See Ditshabe $v$ Sanlam Marketers Retirement Fund (1) 200110 BPLR 2574 (PFA); Ditshabe $v$ Sanlam Marketers Retirement Fund (2) 200110 BPLR 2579 (PFA).

52 See Mhango and Dyani 2009 PER 144 for recent difficulties arising from the third responsibility of the Board under S $37 \mathrm{C}$ of the Act.

53 See Martin 213; Southern Life Association 330. 
Africa, 1996 (hereafter Constitution). More importantly, Murphy's decision was designed to comply with the instruction in Section 39(1) of the Constitution. This section provides that "when interpreting the Bill of Rights, a court, tribunal or forum, must promote the values that underlie an open and democratic society based on human dignity, equality and freedom". ${ }^{54}$ As a result, in Southern Life Association, Murphy indirectly applied the Constitution and interpreted the Act as promoting the rights of pension fund members and their beneficiaries not to be discriminated against on the basis of marital status as contained in Section 9(3) of the Constitution. ${ }^{55}$

However, Murphy's decision differed from that of the subsequent Adjudicator Ngalwana, who, following the decision in Volks (which held that it was permissible for the Maintenance of Surviving Spouses Act to discriminate on the basis of marital status in the provision of maintenance benefits by not recognising the plaintiff, who could have married the deceased but chose not to, as a spouse), held that a person who could have married a deceased pension fund member but chose not to, should not be accorded the benefits of a spouse of a deceased member in the Act. In addition, he decided that in order to qualify as a factual dependant, the surviving cohabitant had to prove that the deceased was the dominant financial provider in their relationship. ${ }^{56}$ These conflicting decisions created uncertainty in the law. The ruling in Van der Merwe left pension funds uncertain regarding whether to consider surviving cohabitants as factual dependants. Many pension funds either sought clarity from the Adjudicator or refused to consider surviving cohabitants as factual dependants on the authority of Volks and Van der Merwe. Others such as the Eskom Pension and Provident Fund adopted policies that incorporated and applied the dominant-servient test as a criterion for dealing with death claims involving surviving cohabitants. For example, following Van der Merwe, the Eskom Pension and Provident Fund adopted a policy to help them deal with death claims, which provides as follows:

54 S 39(1) of the Constitution.

$55 \mathrm{~S} 9(3)$ of the Constitution.

56 See Maritz v Absa Groep Pensioenfonds PFA/GA/1387/00/KM on refusing to grant benefits to surviving life partners or cohabitant on the basis of the precedent established in Van der Merwe. 
If a member dies in service and the Fund receives a claim from a live-in or common-law partner, the Fund will apply the dominant/servant relationship test where the partner who was a member of the Fund was dominant in the relationship, with the surviving partner substantially dependent on the deceased. In such an event, the surviving partner may be considered to benefit from the lump sum death benefit. ${ }^{57}$

Hence, Hlathi should be welcomed because it ensures that the Act is interpreted in a manner that promotes the values that underlie an open and democratic society based on human dignity, equality and freedom. ${ }^{58}$

In the aftermath of Hlathi, there are a number of requirements that pension funds have to take into consideration when dealing with such matters in future. Firstly, the requirements pronounced in Hlathi must fully inform the rules or policies of any registered pension fund when dealing with death claims involving surviving cohabitants. Pension funds, such as the Eskom Pension and Provident Fund, which may have adopted policies or rules in accordance with the dominant-servient test as the basis for dealing with claims involving surviving cohabitants, will have to amend their rules or policies in this regard, and ensure that this test is no longer employed as a basis for qualifying a factual dependant. Instead, pension fund rules or policies should comply with the decision in Hlathi. In addition to this requirement, it is recommended that pension funds request members advise them of the existence of a cohabitant or life partner for purposes of record-keeping. Pension funds could also incorporate the requirements in Hlathi into their rules or policies as evidenced by the Eskom Pension and Provident Fund policy above, which was adopted in reaction to the determination in Van der Merwe. The above recommendations will allow pension funds to keep a record of existing cohabitants or life partners, and assist them to identify the same and dispose of death claims in a procedurally fair, economical and expeditious manner.

Another requirement of Hlathi is that cohabitants are now covered under the Act. Therefore, pension funds may no longer reject death claims arising from surviving cohabitants unless the objective criteria set in Hlathi are not met. A further

57 See Eskom Pension and Provident Fund 2009 /www.eppf.co.za.

58 These are some of the founding values of the Republic of South Africa, S 1(a) and 36(1) Constitution. 
observation of the requirements in Hlathi is that they could potentially lead to the improvement of the lives of many South Africans, who choose not to marry their partners (or to enter into a civil partnership under the Civil Union Act), but live together permanently and continue to have financial dependency on their partner after their partner's death. As the Adjudicator correctly noted in Smith $v$ Eskom Pension and Provident Fund, ${ }^{59}$ "when a breakdown of an intimate relationship takes place, it would be unjust and perhaps callous to ignore complex issues of financial dependency which arise between the parties involved." It is within the context of this observation that Hlathi is likely to improve the lives of surviving cohabitants in South Africa.

\section{$6 \quad$ Criticism of Hlathi v University of Fort Hare Retirement Fund}

While the determination in Hlathi should be welcomed for the reasons that have been provided above, the determination is weak in some respects and should be criticised for failing to adhere to previous determinations comprehensively. Hlathi would have had a much wider impact, had the Adjudicator been consistent in her application of the previous determinations in relation to surviving cohabitants. As indicated earlier, prior to 2005, the Adjudicator had formulated a two-pronged factual dependency test (cohabitants in particular) and consistently applied the test for a period of seven years. ${ }^{60}$ The first question under this test is whether the parties (that is, the party seeking death benefits and the deceased pension member) lived in a relationship of mutual dependence. The second question is whether the parties ran a shared and common household. According to the Adjudicator, the first prong of the test is qualified by the requirement that mutual dependence must involve, amongst other things, an emotional and intimate or sexual bond between the parties. ${ }^{61}$ This test was overruled by Van der Merwe in 2005. Coincidentally, in reversing Van der Merwe, the determination in Hlathi effectively reverted the legal position on these matters back to the pre-Van der Merwe position that was introduced by Murphy in Southern Life Association. However, Hlathi ignored the

5920093 BPLR 343 (PFA - hereafter Smith) para 28, citing Goldblatt 2003 SALJ 614.

60 See Southern Life Association; TWC v Rentokil Pension Fund 20002 BPLR 216 (PFA hereafter TWC); Chittenden v Estcourt Butchery (Pty) Ltd Provident Fund 20015 BPLR 2001 (PFA); Fourie v Central Retirement Annuity Fund 20012 BPLR 1580 (PFA - hereafter Fourie).

61 Mhango (n 1) 130. 
requirement of an emotional and intimate or sexual bond in the new factual dependency test. As a result, this may give rise to a new grey area in the law.

The requirement and application of an emotional and intimate or sexual bond in the factual dependency test is significant because it helps pension funds to distinguish between people who are living together as a husband and wife without the formalities of marriage but with some objective element of permanency, and those such as flatmates and others who live together as a matter of convenience and without a clear indication of permanency of their relationship. South African courts have acknowledged that it is a well established practice in South Africa that people live together either as a consequence of an intimate or sexual relationship or in some instances as a mere matter of convenience, and the question that often confronts boards is the manner in which to distinguish the two for purposes of Section 37C read together with the definition of "dependant" in the Act. ${ }^{62}$ In De Wilzem $v$ South African Retirement Annuity Fund, ${ }^{63}$ the Adjudicator critically examined the lawfulness of considering casual relationships such as flatmates or members of a commune as dependants if they were pooling financial resources. According to the Adjudicator, such persons, even if they could show mutual dependence, were not contemplated by the legislature. The problem is that the reason provided by the Adjudicator in $D e$ Wilzem, which was the application of the dominant-servient theory, was rejected in Hlathi. This requires a different justification for excluding flatmates or members of a commune as dependants within the meaning of the Act. It is suggested that the answer may be found in the application of the requirement of an emotional and intimate or sexual bond because it allows a proper distinction to be drawn between persons who can be considered dependants and those who cannot. In other words, there is no doubt that a flatmate or a member of a commune cannot be considered a dependant under the Act even though they can prove both interdependence under the standard in Hlathi, and that they lived in a relationship of mutual dependence and ran a shared and common household because there will be no element of permanency and, more importantly, no emotional and intimate or sexual bond.

62 See Volks v Robinson 20052 BPLR 101 (CC); Smith (n 32); Satchwell v President of the Republic of South Africa 20041 BPLR 5333 (CC).

6320052 BPLR 180 (PFA - hereafter De Wilzem). 
This note submits that unlike flatmates or members of a commune, a person should qualify as a factual dependant if he/she can establish that they lived in a relationship of mutual dependence or interdependence, involving an emotional and intimate or sexual bond, and ran a shared and common household. The latter proposition is supported by the Adjudicator's determination in Fourie. In this case, the Adjudicator upheld the Board's decision, in particular on the basis that a person who had previously for a period of nine years lived with a deceased member in a relationship of mutual dependence involving an intimate and emotional or sexual bond and a shared common household, but who had then amicably severed this relationship to merely maintain a platonic relationship, does not qualify as a factual dependant. ${ }^{64}$ In other cases, the Adjudicator has emphasised the need for the requirement of an emotional and intimate or sexual bond, and appears to have required evidence of an intimate or emotional bond or at least evidence from which a reasonable inference of such a bond can be made. ${ }^{65}$

Given the above observations, this note submits that the failure by the Adjudicator to expressly endorse the emotional and intimate or sexual bond requirement creates a potential and unnecessary ambiguity in the law that needs to be clarified. While some commentators have criticised the emotional and intimate or sexual bond requirement as having no significance in the application of Section $37 \mathrm{C}$, it is submitted that this remains relevant in the application of Section $37 \mathrm{C}$ given previous cases and the changing societal views on relationships. ${ }^{66}$ For example, this note submits that it is not persuasive to maintain that Section $37 \mathrm{C}$ was intended to cover a couple who dated and cohabited for a period of twelve months, but continue to live together (as flatmates) because of financial convenience and uncertainty as to whether they remain permanently committed to each other. In other words, this note concurs with the Adjudicator in De Wilzem that Section 37C was not intended to apply to flatmates or members of a commune. In these circumstances, the requirement of an emotional and intimate or sexual bond becomes relevant to determining whether the surviving cohabitant qualifies as a factual dependant within

64 De Wilzem and Mhango ( $\mathrm{n} 1$ ) 132.

65 Mhango (n 1) 133, citing Fourie and TWC.

66 Khumalo 2008 "Death Benefits Under Section 37C of the Act " argued against the emotional and intimate or sexual bond requirement on the basis that it has no relevance to the question of dependence. 
the scope of Hlathi. Therefore, while Hlathi should be welcomed for the reasons indicated above, as it has been by the pension funds industry and academics, ${ }^{67}$ it should be criticised for its failure to re-establish fully the factual dependency test that prevailed prior to Van der Merwe. It is important to note that despite the above criticism, the emotional and intimate or sexual bond requirement may still form part of the new test because it may not have been necessary or relevant for the Adjudicator to mention it in the context of the facts in Hlathi, hence its omission. In other words, it is possible that the requirement of an emotional and intimate or sexual bond was not expressly addressed by the Adjudicator because the facts of the case did not permit this, and that in all appropriate circumstances the requirement remains relevant and applicable. Nevertheless, since it is not clear whether the omission of the emotional and intimate or sexual bond requirement was a considered decision by the Adjudicator or a mere oversight, this note recommends that the future Adjudicator clarify this point of law.

\section{Conclusion}

This note has critically discussed Hlathi, which dealt with the question of whether a surviving cohabitant who was in an inter-dependent relationship with the deceased may qualify as a factual dependant under the Act. It was decided in Hlathi that a cohabitant qualifies as a factual dependant if he/she can establish the existence of a permanent relationship of mutual dependency or inter-dependency, and that he/she shared a common household with the deceased pension fund member.

In this note, it has been argued that the determination in Hlathi should be welcomed because it clarifies the law and uncertainties that emerged following the ruling in Volks. This note has demonstrated that the legal position on these matters has reverted to the position that prevailed between 1998 and 2005, and has criticised what appears to be an omission of an important element of the factual dependency test, which is that a relationship of mutual dependency must involve an emotional and intimate or sexual bond. This note has suggested that the Adjudicator should continue to apply this element because it remains relevant within the context of

67 Dyani Speculum Juris (forthcoming). See Nevondwe 2009 Insurance and Tax Journal. 
Section 37C, that the omission of this element may have been an oversight, and that this element remains part of the factual dependency test to be applied by boards of pension funds in relevant cases.

\section{Bibliography}

\section{Dyani Speculum Juris}

Dyani N "Distribution of death benefits in terms of Section 37C of the Pension Funds Act: Rejecting the dominant-servient test in cases of cohabitation" Speculum Juris (forthcoming)

Goldblatt SALJ

Goldblatt B "Regulating domestic partnerships: A necessary step in the development of South African family law" 2003 SALJ 120 610-629

Khumalo "Death Benefits Under Section 37C of the Act" Khumalo S "Death Benefits Under Section 37C of the Act" (Unpublished paper delivered at the Pension Lawyers Association of South Africa Conference 7 May 2008 Sandton)

\section{Manamela SA Merc LJ}

Manamela T "Chasing Away the Ghost in Death Benefits: A Closer Look at Section 37C of the Pension Funds Act 24 of 1956" 2005 SA Merc LJ 278-279

Marx and Hanekom Manual

Marx GL and Hanekom K (eds) The Manual on South African Retirement Funds and other Employee Benefits Volume 1 (LexisNexis Durban 2007)

\section{Mhango SA Merc LJ}

Mhango MO "An Examination of the Accurate Application of the Dependency Test under the Pension Funds Act 24 of 1956: Case Comments" 2008 SA Merc LJ 126-135 
Mhango and Dyani PER

Mhango MO and Dyani N "The Duty to Effect an Appropriate Mode of Payment to Minor Pension Beneficiaries under Scrutiny in Death Claims" 2009 12(2) PER 144-168

Nevondwe Insurance and Tax Journal

Nevondwe L "Cohabitation versus Section 37C of the Pension Funds Act, 24 of 1956" 2009 Insurance and Tax Journal June 8-13

Wood-Bodley SALJ

Wood-Bodley MC "Freedom of Testation and the Bill of Rights: Minister of Education v Syfrets Trust Ltd" 2007 SALJ 687-702

\section{Register of legislation}

Civil Union Act 17 of 2006

Constitution of the Republic of South Africa, 1996

Maintenance of Surviving Spouses Act 27 of 1990

Pension Funds Act 24 of 1956

Pension Funds Amendment Act 11 of 2007

\section{Register of court cases}

Chittenden v Estcourt Butchery (Pty) Ltd Provident Fund and Another 20015 BPLR 2001 (PFA)

Cockcroft v Mine Employees Pension Fund 20073 BPLR 296 (PFA)

De Wilzem and Another $v$ South African Retirement Annuity Fund 20052 BPLR 180 (PFA)

Ditshabe v Sanlam Marketers Retirement Fund (1) 200110 BPLR 2574 (PFA)

Ditshabe v Sanlam Marketers Retirement Fund (2) 200110 BPLR 2579 (PFA)

Dobie NO v National Technikon Retirement Pension Fund 19999 BPLR 29 (PFA)

Fourie v Central Retirement Annuity Fund 20012 BPLR 1580 (PFA)

Hlathi v University of Fort Hare Retirement Fund and Others 20091 BPLR 37 (PFA) 
Jacobs NO v Central Retirement Annuity Fund and Another 20011 BPLR 1488 (PFA)

Kaplan and Another NNO v Professional and Executive Retirement Fund and Others 200110 BPLR 2541 (W)

Malatjie $v$ ldwala Provident Fund 20051 BPLR 45 (PFA)

Maritz $v$ Absa Groep Pensioenfonds PFA/GA/1387/00/KM (unreported)

Martin v Beka Provident Fund 20002 BPLR 196 (PFA)

Mashazi v African Products Retirement Benefit Provident Fund 20028 BPLR 3703

(W)

Matene v Noordberg Group Life-Assurance Scheme 20012 BPLR 1604 (PFA)

Mthiyane v Fedsure Life Assurance Ltd and Others 20017 BPLR 2230 (PFA)

Musgrave $v$ Unisa Retirement Fund 20004 BPLR 415 (PFA)

Ramanyelo v Mine Workers Provident Fund 20051 BPLR 67 (PFA)

Satchwell $v$ President of the Republic of South Africa and Another 20041 BPLR

5333 (CC)

Sithole v ICS Provident Fund and Another 20004 BPLR 430 (PFA)

Smith $v$ Eskom Pension and Provident Fund 20093 BPLR 343 (PFA)

TWC and Others $v$ Rentokil Pension Fund and Another 20002 BPLR 216 (PFA)

Van de Berg v Durban Pension Fund 20033 BPLR 4518 (PFA)

Van der Merwe and Another $v$ Central Retirement Annuity Fund and Another 20055

BPLR 463 (PFA)

Van der Merwe and Others v The Southern Life Association Ltd and Another 20003

BPLR 321 (PFA)

Van Zyl v Delta Motor Corporation Salaried Provident Fund and Another

PFA/EC/698/04/Z/CN (unreported)

Volks NO v Robinson and Others 20055 BCLR 446 (CC)

Wasserman v Central Retirement Annuity 20016 BPLR 2160 (PFA)

Wellens v Unsgaard Pension Fund 200212 BPLR 4214 (PFA) 


\section{Register of internet sources}

Eskom Pension and Provident Fund www.eppf.co.za

Eskom Pension and Provident Fund 2009 Member's guide to benefits http://www.eppf.co.za/members/Members\%20Guide.pdf [date of use 6 Nov 2009]

\section{List of abbreviations}

PER

Potchefstroomse Elektroniese Regsblad (Potchefstroom Electronic Law Journal)

SALJ South African Law Journal

SA Merc LJ

South African Mercantile Law Journal 